Editorial

\title{
Publisher's Note: The Correct ISSN 2227-7102 for Education Sciences
}

\section{Shu-Kun Lin}

MDPI AG, Postfach, CH-4005 Basel, Switzerland; E-Mail: lin@mdpi.com

Received: 3 December 2012 / Published: 5 December 2012

As the registered title of our journal was changed from "Education (Basel)" (ISSN 2076-3344) to "Education Sciences" (ISSN 2227-7102) in May 2012, we mistakenly continued publishing under the old ISSN number instead of the new one. We would like to clarify that the ISSN number on the first pages of the following published papers is incorrect. The correct ISSN number should be 2227-7102.

- Lin, S.-K. Publisher's Note: Education to Education Sciences. Educ. Sci. 2012, 2, 56.

- Maguth, B.M. Investigating Student Use of Technology for Engaged Citizenship in A Global Age. Educ. Sci. 2012, 2, 57-76.

- Sarmento, T.; Freire, I. Making School Happen: Children-Parent-Teacher Collaboration as A Practice of Citizenship. Educ. Sci. 2012, 2, 105-120.

- Kennedy, K.J. Global Trends in Civic and Citizenship Education: What are the Lessons for Nation States? Educ. Sci. 2012, 2, 121-135.

- Shen, Z.; Jensen, W.; Wentz, T.; Fischer, B. Teaching Sustainable Design Using BIM and Project-Based Energy Simulations. Educ. Sci. 2012, 2, 136-149.

- Wolbring, G. Citizenship Education through an Ability Expectation and "Ableism" Lens: The Challenge of Science and Technology and Disabled People. Educ. Sci. 2012, 2, 150-164.

We apologize for any inconvenience this may have caused.

(C) 2012 by the authors; licensee MDPI, Basel, Switzerland. This article is an open access article distributed under the terms and conditions of the Creative Commons Attribution license (http://creativecommons.org/licenses/by/3.0/). 